\title{
Screening of Pyruvate Kinase Deficiency and G6PD Deficiency in Chinese Newborn in Hong Kong
}

\author{
ROBERT H. P. FUNG, YEUNG KWOK KEUNG, and GABRIEL S. H. CHUNG \\ From the Queen Mary and Tsan Yuk Hospitals, Hong Kong
}

In recent reports, pyruvate kinase deficiency (PK deficiency) and glucose-6-phosphate dehydrogenase (G6PD) deficiency appear to be the most common deficiencies associated with the syndrome of congenital non-spherocytic haemolytic anaemia. Many of these cases have been reported to be associated with neonatal jaundice of varying degrees of severity. This study was undertaken to find the incidence of PK deficiency and G6PD deficiency in the Chinese newborn in Hong Kong, and the possible relation of PK deficiency with neonatal jaundice. The relation of G6PD deficiency and neonatal jaundice had been well established in many studies throughout the world including Chinese neonates in Hong Kong.

\section{Material and Methods}

From March 1, 1968, to May 5, 1968, 700 consecutive newborn babies born at Tsan Yuk Hospital were screened for PK and G6PD deficiencies. The methods used were described by Beutler (1966). In these procedures, advantage is taken of the fact that even minute quantities of reduced pyridine nucleotides fluoresce intensely when activated with long-wave ultraviolet light. These tests are based upon the reduction of oxidized pyridine nucleotide in the case of G6PD deficiency, or on the oxidation of a reduced pyridine nucleotide in the case of PK deficiency. In G6PD deficiency, there is absence of fluorescence under long-wave ultraviolet light, whereas the fluorescence persists after incubation in PK deficiency. In Beutler's original description of his method, detection of the heterozygote in G6PD deficiency presents more of a problem than in PK deficiency because of the rapidity of the reaction time in the former. In this study, we made no attempt to separate the heterozygote from the homozygote in G6PD deficient individuals. However, in PK deficiency Beutler showed that homozygous individuals uniformly showed persistence of the fluorescence 1 hour or more after incubation at $37^{\circ} \mathrm{C}$. while heterozygote individuals showed disappearance of the fluorescence before 1 hour but later than normal individuals, i.e. after 15 minutes of incubation. In

Received November 8, 1968. this study, readings of the fluorescence were taken at 0,15 , and 60 minutes of incubation. Disappearance of fluorescence at or before 15 minutes was considered normal; persistence of fluorescence at 15 minutes but disappearance at 60 minutes was considered to imply partial deficiency of PK (heterozygote), and persistence of fluorescence at 1 hour or more was considered to imply total PK deficiency (homozygote). Since this is a screening procedure, no attempts were made to assay the actual level of PK enzyme in each individual.

TABLE I

Incidence of G6PD and PK Deficient Babies

\begin{tabular}{|c|c|c|c|c|c|}
\hline \multirow[b]{2}{*}{ Sex } & \multirow{2}{*}{$\begin{array}{l}\text { No. of } \\
\text { Babies }\end{array}$} & \multicolumn{2}{|c|}{ G6PD Deficient } & \multicolumn{2}{|c|}{ PK Deficient } \\
\hline & & $\begin{array}{l}\text { No. of } \\
\text { Babies }\end{array}$ & $\%$ & $\begin{array}{l}\text { No. of } \\
\text { Babies }\end{array}$ & $\%$ \\
\hline $\begin{array}{ll}\text { Male } & \ldots \\
\text { Female } & \ldots\end{array}$ & $\begin{array}{l}377 \\
323\end{array}$ & $\begin{array}{l}9 \\
2\end{array}$ & $\begin{array}{l}2 \cdot 4 \\
0.6\end{array}$ & $\begin{array}{r}16 \\
8\end{array}$ & $\begin{array}{l}4 \cdot 2 \\
2 \cdot 4\end{array}$ \\
\hline $\begin{array}{c}\text { Total no. of } \\
\text { babies } .\end{array}$ & 700 & 11 & $1 \cdot 6$ & 24 & $3 \cdot 4$ \\
\hline
\end{tabular}

\section{Results}

As shown in Table $\mathrm{I}$, of the 700 babies screened 323 were female and 377 were male. 11 babies were found to be G6PD deficient (1.6\%), and 24 babies to be PK deficient (3.4\%). One baby had both G6PD and PK deficiency.

Of the 11 babies who were G6PD deficient, 9 were male $(2 \cdot 4 \%)$ and 2 were female $(0 \cdot 6 \%)$.

Of the 24 babies who were PK deficient, 16 were male $(4 \cdot 2 \%)$ and 8 were female $(2 \cdot 4 \%)$. Of the 24 babies 8 showed complete PK deficiency; 16 babies showed partial PK deficiency (Table II).

As can be seen from Table III, 16 out of 24 babies $(66 \%)$ developed neonatal jaundice with peak bilirubin levels up to $18.4 \mathrm{mg}$. $/ 100 \mathrm{ml}$. in one baby. Of the 16 babies, 9 had no other known causes of neonatal jaundice, e.g. prematurity, G6PD deficiency, ABO incompatibility, sepsis, etc. The average duration of jaundice was 6 days. None required exchange transfusions. Blood smear, 
TABLE II

Incidence of Homozygous and Heterozygous PK Deficiency

\begin{tabular}{|c|c|c|c|c|c|}
\hline & & & & $\begin{array}{c}\text { Partial PK } \\
\text { Deficiency } \\
\text { (heterozygote) }\end{array}$ & $\begin{array}{c}\text { Total PK } \\
\text { Deficiency } \\
\text { (homozygote) }\end{array}$ \\
\hline $\begin{array}{l}\text { Male } \\
\text { Female }\end{array}$ & $\begin{array}{l}\cdots \\
\cdots\end{array}$ & $\begin{array}{l}\cdots \\
\cdots\end{array}$ & $\cdots$ & $\begin{array}{r}10 \\
6\end{array}$ & $\begin{array}{l}6 \\
2\end{array}$ \\
\hline Total & .. & $\ldots$ & .. & 16 & 8 \\
\hline
\end{tabular}

$\mathrm{Hb}$, and reticulocyte counts were done on the day of the peak bilirubin level, and were normal in most cases.

As can be seen from Table IV, of the 11 babies with G6PD deficiency 9 were male and 2 were female. All had neonatal jaundice, the average duration of jaundice being 6 days. None required exchange transfusions. One male baby had a family history of G6PD deficiency in a brother.

\section{Discussion}

The increased incidence of neonatal jaundice in babies with G6PD deficiency has been well documented and the results of this survey of Hong Kong neonates is in keeping with these reports (Yue and Strickland, 1965). There is much less information about the relation of PK deficiency to neonatal jaundice. Since Tanaka, Valentine, and Miwa (1962) first reported cases of PK deficiency, over 80 cases of homozygous PK deficiency can be found in the European, American, and Japanese literature (Oski and Diamond, 1963; Keitt, 1966; Oski et al., 1964; Volpata, Vigi, and Cattarozzi, 1968). In at least 15 of these the disease began at birth, with severe neonatal jaundice requiring exchange transfusion. This defect is inherited as an autosomal recessive, and only the homozygous individuals are liable to increased haemolysis, the heterozygotes usually showing no clinical symptoms. In the present study, all the homozygous PK deficient babies had neonatal jaundice, while a little over half the heterozygote babies also exhibited neonatal jaundice.

In view of the large number of babies with neonatal jaundice with no known cause in Hong Kong, we undertook this study to see if PK deficiency, partial or complete, was present in the

TABLE III

Pyruvate Kinase Deficient Babies

\begin{tabular}{|c|c|c|c|c|c|c|c|c|c|c|c|c|c|c|}
\hline \multirow{2}{*}{$\begin{array}{l}\text { Case } \\
\text { No. }\end{array}$} & \multirow[b]{2}{*}{ Sex } & \multirow{2}{*}{$\begin{array}{c}\text { Maturity } \\
\text { (wk.) }\end{array}$} & \multicolumn{2}{|c|}{ Peak Bilirubin } & \multirow{2}{*}{$\begin{array}{c}\text { Duration } \\
\text { of } \\
\begin{array}{c}\text { Jaundice } \\
\text { (days) }\end{array}\end{array}$} & \multicolumn{2}{|c|}{ Blood Group } & \multirow{2}{*}{$\begin{array}{l}\text { Other } \\
\text { Possible } \\
\text { Cause of } \\
\text { Jaundice }\end{array}$} & \multicolumn{2}{|c|}{$\mathrm{Hb}$} & \multicolumn{2}{|c|}{ Retics } & \multicolumn{2}{|c|}{ PK Deficient } \\
\hline & & & $\begin{array}{c}\text { (mg.l } \\
100 \mathrm{ml} .)\end{array}$ & Day & & Mother & Baby & & $\begin{array}{c}\text { (g./ } \\
100 \mathrm{ml} .)\end{array}$ & Day & $\%$ & Day & Partial & Total \\
\hline $\begin{array}{l}1 \\
2\end{array}$ & $\begin{array}{c}\mathrm{M} \\
\mathrm{F}\end{array}$ & $\begin{array}{l}41 \\
35\end{array}$ & $\begin{array}{l}15 \cdot 1 \\
12 \cdot 9\end{array}$ & $\begin{array}{l}5 \\
5\end{array}$ & $\begin{array}{l}8 \\
6\end{array}$ & $\begin{array}{l}\mathbf{A} \\
\mathbf{A}\end{array}$ & $\begin{array}{l}\mathbf{O} \\
\mathbf{A B}\end{array}$ & $\begin{array}{l}\text { None } \\
\text { Prematu- } \\
\text { rity }\end{array}$ & $\begin{array}{l}11 \cdot 8 \\
17 \cdot 9\end{array}$ & $\begin{array}{l}5 \\
5\end{array}$ & $\begin{array}{l}4 \cdot 7 \\
1 \cdot 1\end{array}$ & $\begin{array}{l}5 \\
5\end{array}$ & & $\begin{array}{l}+ \\
+\end{array}$ \\
\hline 3 & $\mathbf{M}$ & 39 & $18 \cdot 4$ & 5 & 9 & B & O & $\begin{array}{c}\text { G6PD de- } \\
\text { ficient }\end{array}$ & - & - & - & 一 & & + \\
\hline $\begin{array}{l}4 \\
5\end{array}$ & $\mathbf{F}$ & 40 & \multirow{2}{*}{\multicolumn{2}{|c|}{$\begin{array}{l}\text { No jaundice } \\
\text { No jaundice } \\
\text { No jaundice }\end{array}$}} & & $\mathbf{A B}$ & $\mathbf{A}$ & - & $\overline{-}$ & - & - & - & + & \\
\hline $\begin{array}{l}3 \\
6\end{array}$ & $\mathbf{M}$ & $\begin{array}{l}40 \\
40\end{array}$ & & & & A & O & - & $15 \cdot 4$ & 8 & 0.4 & $\overline{8}$ & + & \\
\hline 7 & $\mathbf{M}$ & 38 & $14 \cdot 5$ & 5 & 5 & $\mathbf{O}$ & $\mathbf{O}$ & $\underset{\text { sticky }}{\text { Umbilicus }}$ & 15 & 2 & - & - & + & \\
\hline 8 & $\mathbf{M}$ & 43 & $15 \cdot 3$ & 5 & 4 & B & B & $\underset{\text { sticky }}{\text { Umbilicus }}$ & $11 \cdot 8$ & 4 & 22 & 4 & + & \\
\hline 9 & $\mathbf{F}$ & 36 & \multirow{2}{*}{\multicolumn{2}{|c|}{$\begin{array}{l}\text { No jaundice } \\
\text { No jaundice }\end{array}$}} & & $\mathbf{O}$ & $\mathbf{O}$ & - & 一 & - & - & 一 & + & \\
\hline 10 & $\mathbf{M}$ & 41 & & & & $\mathbf{O}$ & A & - & - & - & - & 一 & + & \\
\hline 11 & $\mathbf{M}$ & 38 & $10 \cdot 5$ & 4 & 5 & $\mathbf{O}$ & $\mathbf{O}$ & $\begin{array}{c}\text { Umbilicus } \\
\text { sticky }\end{array}$ & 13 & 3 & 2 & 3 & + & \\
\hline 12 & $\mathbf{M}$ & 40 & 134 & 7 & 5 & A & $\mathbf{O}$ & None & 15 & 2 & 0.1 & 2 & + & \\
\hline 13 & $\mathbf{M}$ & 38 & $12 \cdot 3$ & 6 & 5 & $\mathbf{O}$ & $\mathbf{O}$ & None & $15 \cdot 2$ & 5 & 0.6 & 5 & + & \\
\hline 14 & $\mathbf{M}$ & 39 & $11 \cdot 9$ & 4 & 6 & O & B & $\begin{array}{c}\text { Umbilicus } \\
\text { sticky }\end{array}$ & $14 \cdot 6$ & 4 & $3 \cdot 2$ & 4 & & + \\
\hline 15 & $\mathbf{F}$ & 41 & $9 \cdot 1$ & 5 & 4 & $\mathbf{O}$ & B & None & $13 \cdot 5$ & 4 & $1 \cdot 2$ & 4 & & $+t$ \\
\hline 16 & $\mathbf{M}$ & 39 & $13 \cdot 0$ & 3 & 7 & A & $\mathbf{O}$ & None & $14 \cdot 0$ & 5 & 0.9 & 5 & & + \\
\hline 17 & $\mathbf{F}$ & 39 & \multicolumn{2}{|c|}{ No jaundice } & & B & B & - & - & - & - & - & + & \\
\hline 18 & $\mathbf{M}$ & 38 & $9 \cdot 0$ & 5 & 3 & $\mathbf{A B}$ & $\mathbf{A B}$ & - & 14 & 5 & $1 \cdot 0$ & 5 & + & \\
\hline 19 & $\mathbf{F}$ & 39 & \multicolumn{2}{|c|}{ No jaundice } & & A & $\mathbf{O}$ & - & - & - & - & - & + & \\
\hline 20 & $\mathbf{M}$ & 38 & $17 \cdot 1$ & 7 & 14 & B & B & None & $15 \cdot 8$ & 6 & $1 \cdot 1$ & 6 & & + \\
\hline 21 & F & 39 & \multicolumn{2}{|c|}{ No jaundice } & & $\mathbf{A B}$ & B & - & - & 一 & - & 一 & + & \\
\hline 22 & $\mathbf{M}$ & 39 & $7 \cdot 4$ & 4 & 4 & $\mathbf{0}$ & A & None & $14 \cdot 6$ & 5 & $0 \cdot 1$ & 5 & + & \\
\hline 23 & $\mathbf{F}$ & 39 & $12 \cdot 0$ & 6 & 5 & A & A & None & $15 \cdot 0$ & 6 & $1 \cdot 2$ & 6 & + & \\
\hline 24 & $\mathbf{M}$ & 40 & $16 \cdot 4$ & 5 & 6 & A & $\mathbf{A}$ & None & $12 \cdot 3$ & 5 & 2 & 5 & & + \\
\hline
\end{tabular}

$+=$ degree of PK deficiency 
TABLE IV

G6PD Deficient Babies

\begin{tabular}{|c|c|c|c|c|c|c|c|c|}
\hline \multirow{2}{*}{$\begin{array}{l}\text { Case } \\
\text { No. }\end{array}$} & \multirow{2}{*}{ Sex } & \multirow{2}{*}{$\begin{array}{l}\text { Maturity } \\
\text { (wk.) }\end{array}$} & \multicolumn{2}{|c|}{ Peak Bilirubin } & \multirow{2}{*}{$\begin{array}{c}\text { Duration of } \\
\text { Jaundice } \\
\text { (days) }\end{array}$} & \multicolumn{2}{|c|}{ Blood Group } & \multirow{2}{*}{ Comments } \\
\hline & & & (mg./100 ml.) & On Day & & Mother & Baby & \\
\hline $\begin{array}{r}1 \\
2 \\
3 \\
4 \\
5 \\
6 \\
7 \\
8 \\
9 \\
10 \\
11\end{array}$ & $\begin{array}{l}\mathbf{F} \\
\mathbf{M} \\
\mathbf{M} \\
\mathbf{F} \\
\mathbf{M} \\
\mathbf{M} \\
\mathbf{M} \\
\mathbf{M} \\
\mathbf{M} \\
\mathbf{M} \\
\mathbf{M}\end{array}$ & $\begin{array}{l}47 \\
31 \\
40 \\
34 \\
39 \\
40 \\
39 \\
41 \\
39 \\
41 \\
40\end{array}$ & $\begin{array}{c}14 \cdot 7 \\
<10 \\
17 \cdot 7 \\
16 \cdot 9 \\
18 \cdot 4 \\
13 \cdot 7 \\
14 \cdot 4 \\
10 \cdot 4 \\
<10 \\
14 \cdot 3 \\
12 \cdot 4\end{array}$ & $\begin{array}{l}4 \\
4 \\
6 \\
5 \\
2 \\
6 \\
3 \\
5 \\
5 \\
4\end{array}$ & $\begin{array}{r}4 \\
3 \\
6 \\
10 \\
9 \\
4 \\
6 \\
3 \\
4 \\
9 \\
6\end{array}$ & $\begin{array}{l}\text { B } \\
\text { B } \\
\text { B } \\
\text { A } \\
\text { B } \\
\text { O } \\
\text { B } \\
\text { O } \\
\text { A } \\
\text { O } \\
\text { A }\end{array}$ & $\begin{array}{l}\text { B } \\
\text { B } \\
\text { B } \\
\text { O } \\
\text { O } \\
\text { O } \\
\text { A } \\
\text { O } \\
\text { B } \\
\text { O } \\
\text { B }\end{array}$ & $\begin{array}{l}\text { Also PK deficient } \\
\text { Elder brother G6PD deficient }\end{array}$ \\
\hline
\end{tabular}

population of neonates. It is clear that PK deficiency is present in a significant percentage of the Chinese neonates in Hong Kong. Though we did not perform assay of the PK enzyme in the deficient individuals, it seems that many of these are only partially deficient in PK. The exact relation between PK deficiency (complete or partial) and neonatal jaundice in these babies was not clearly defined in this study. It is interesting to note, further, that family studies were done on several of the deficient babies. These studies correlate well with the literature regarding the mode of inheritance of the PK deficient gene.

The autosomal recessive nature of the inheritance of this PK deficiency is again demonstrated by the four examples shown in the Fig.

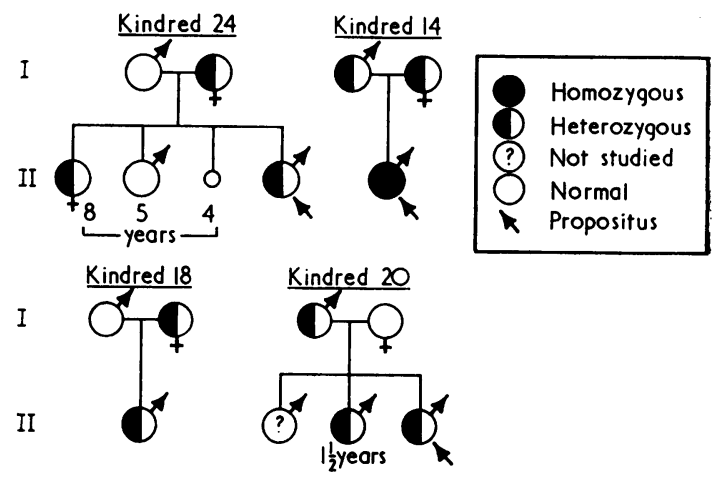

FIG.-Inheritance of pyruvate kinase deficiency in four kindreds. The pattern is compatible with an autosomal recessive inheritance.

\section{Summary}

Screening of 700 consecutive newborn babies in a maternity hospital in Hong Kong showed that a significant number of babies had pyruvate kinase deficiency, as well as G6PD deficiency. The incidence of neonatal jaundice of these babies was high. The precise relation between these enzyme deficiencies and increased incidence and severity of neonatal jaundice still needs to be elucidated.

We thank Professor C. E. Field and Professor Daphne Chun for their encouragement in this work; Dr. Y. C. Tsao for his constructive critique; and Mr. K. C. Nip and Mr. Peter Cheung for their technical assistance.

\section{REFERENCES}

Beutler, E. (1966). A series of new screening procedures for pyruvate kinase deficiency, glucose-6-phosphate dehydrogenase deficiency, and glutathione reductase deficiency. Blood, 28, 553.

Keitt, A. S. (1966). Pyruvate kinase deficiency and related disorders of red cell glycolysis. Amer. F. Med., 41, 762.

Oski, F. A., and Diamond, L. K. (1963). Erythrocyte pyruvate kinase deficiency resulting in congenital non-spherocytic hemolytic anemia. New Engl. F. Med., 269, 763.

-, Nathan, D. G., Sidel, V. W., and Diamond, L. K. (1964). Extreme hemolysis and red-cell distortion in erythrocyte pyruvate kinase deficiency. I. Morphology, erythrokinetics and family enzyme studies. ibid., 270, 1023.

Tanaka, K. R., Valentine, W. N., and Miwa, S. (1962). Pyruvate kinase (PK) deficiency hereditary non-spherocytic hemolytic anemia. Blood, 19, 267.

Volpata, S., Vigi, V., and Cattarozzi, G. (1968). Nonspherocytic haemolytic anaemia and severe jaundice in a newborn with partial pyruvate kinase deficiency. Acta paediat. scand., 57, 59.

Yue, P. C. K., and Strickland, M. (1965). Glucose-6-phosphatedehydrogenase deficiency and neonatal jaundice in Chinese male infants in Hong Kong. Lancet, 1, 350.

Correspondence to Dr. Robert Fung, Department of Paediatrics, Queen Mary Hospital, Hong Kong.

\section{Addendum}

In a study involving PK screening of babies with neonatal jaundice admitted to the Department of Paediatrics, Queen Mary Hospital, 12 out of 130 babies 
(11\%) were found to be PK deficient. One female baby was perfectly well after birth, but on day 6 , there was a sudden onset of jaundice with no apparent known cause: when admitted to hospital on day 7, the bilirubin level had risen to $36 \mathrm{mg} . / 100 \mathrm{ml}$., and signs of kernikterus were evident. No exchange transfusion was done and the baby died the next day. PK determinations showed complete deficiency, and no other known cause of neonatal jaundice was found. 2 other female babies with PK deficiency have presented with sudden onset of rapidly increasing jaundice and have required exchange transfusions. 